\title{
FAKTOR PENDORONG DAN PENGHAMBAT WANITA PEKERJA SEKS (WPS) DI DENPASAR UNTUK MELAKUKAN PAP SMEAR/IVA SEBAGAI UPAYA PENCEGAHAN KANKER SERVIKS TAHUN 2017
}

\author{
Gusti Ayu Ikha Adyastuty Sanatha*, Ni Wayan Septarini, Desak Putu Yuli Kurniati \\ Program Studi Kesehatan Masyarakat Fakultas Kedokteran Universitas Udayana \\ *Email: ayuikhasanatha@yahoo.co.id
}

\begin{abstract}
ABSTRAK
Kanker serviks menempati urutan kedua di dunia setelah kanker payudara. Pada tahun 2016, kasus baru kanker serviks terbanyak di Bali ditemukan di Kota Denpasar sebanyak 834 kasus dan meninggal sebanyak 12 orang. Wanita Pekerja Seks berisiko untuk menderita kanker serviks karena sering berganti-ganti pasangan seksual dan berhubungan seksual pada usia dini. Tujuan dari penelitian ini adalah untuk mengetahui faktor pendorong dan penghambat Wanita Pekerja Seks (WPS) di Denpasar untuk melakukan Pap Smear/IVA sebagai upaya pencegahan kanker serviks tahun 2017. Penelitian ini merupakan penelitian deskriptif kuantitatif dengan menggunakan metode cross-sectional. Jumlah sampel pada penelitian ini sebanyak 82 wanita pekerja seks langsung dengan menggunakan teknik quota sampling. Pengumpulan data dilakukan dengan menggunakan kuesioner dan data dianalisis secara univariat dan bivariat. Dari hasil penelitian ditemukan bahwa sebagian besar wanita pekerja seks langsung di Kota Denpasar berumur $<35$ tahun $(74,4 \%)$, berpendidikan rendah $(92,7 \%)$, dan berasal dari luar Bali (98,8\%). Faktor pendorong wanita pekerja seks langsung untuk melakukan Pap Smear/IVA adalah faktor biaya Pap Smear terjangkau (64,6\%) dan biaya IVA terjangkau (100\%), serta akses ke fasilitas kesehatan dekat (68,3\%). Faktor penghambat untuk melakukan pemeriksaan Pap Smear/IVA adalah pengetahuan kurang $(79,3 \%)$, bersikap negatif $(81,7 \%)$, tidak pernah mendapat sumber informasi $(72 \%)$, fasilitas dan sarana kesehatan tidak tersedia $(76,8 \%)$, tidak mendapat dukungan teman $(85,4 \%)$ dan petugas kesehatan $(73,2 \%)$. Penyebaran informasi tentang pencegahan kanker serviks yang lebih intensif dengan meningkatkan peran serta tenaga kesehatan diharapkan mampu menurunkan kejadian kanker serviks dan meningkatkan kemauan Wanita Pekerja Seks untuk melakukan pemeriksaan Pap Smear/IVA.
\end{abstract}

Kata Kunci: Faktor Pendorong, Faktor Penghambat, Wanita Pekerja Seks, Pap Smear, IVA

\begin{abstract}
Cervical cancer is second in the world after breast cancer. In 2016, the most new cases of cervical cancer in Bali were found in Denpasar City with 834 cases and 12 people died. Female Sex Workers who are at risk for cervical cancer due to frequent changing of sex partners and having sex at an early age. The purpose of this study was to know the factors driving and inhibiting female sex workers (WPS) in Denpasar to conduct Pap Smear / IVA as an effort to prevent cervical cancer in 2017. This research is a descriptive study using cross-sectional methods. The number of samples in this study were 82 direct female sex workers using the quota sampling technique. Data collection was performed using a questionnaire and data were analyzed univariately and bivariately. From the results of the study it was found that most direct sex workers in the City of Denpasar were $<35$ years $(74.4 \%)$, had low education $(92.7 \%)$, and came from outside Bali $(98.8 \%)$. The driving factors for direct female sex workers to have Pap Smear / IVA are the affordable Pap Smear cost (64.6\%) and the affordable IVA cost (100\%), as well as access to close health facilities (68.3\%). The inhibiting factors for Pap Smear / IVA test are lack of knowledge (79.3\%), negative thinking $(81.7 \%)$, never getting information sources $(72 \%)$, health facilities and facilities not available $(76.8 \%)$, did not have the support of friends $(85.4 \%)$ and health workers $(73.2 \%)$. Dissemination of information about increasing cervical cancer more intensively by increasing the role and improvement of health related to increased cervical cancer and increasing the willingness of Female Sex Workers to do Pap Smear / IVA. Keywords: Encourage Factors, Inhibiting Factors, Female Sex Workers, Pap Smear, IVA
\end{abstract}

\section{PENDAHULUAN}

Kanker mulut rahim atau kanker serviks adalah suatu proses keganasan yang terjadi pada serviks. Kanker serviks merupakan jenis kanker terbanyak kedua di dunia setelah kanker payudara. Pada tahun 2012, diperkirakan 527.600 kasus baru terjadi di seluruh dunia, dengan angka kematian hampir 265.700 jiwa (American Cancer Society, 2015).

Pada tahun 2010 diberapa Negara maju melakukan skrining kanker serviks dengan 
Pap Smear terbukti mampu menurunkan angka kejadian kanker serviks hingga 90\% dan menurunkan mortalitas hingga 70$80 \%$. Namun penyelenggaraan tes Pap Smear di Indonesia sangat sulit di laksanakan, sehingga ada salah satu metode alternatif skrining kanker serviks yang lebih sederhana yaitu Inspeksi Visual Asam Asetat (Aminati, 2013).

Angka kejadian kanker serviks di Indonesia menurut Departemen Kesehatan RI 2010 mencapai angka 100 per 100.000 penduduk pertahun dan tanpa penatalaksanaan yang adekuat, diperkirakan kematian akibat kanker serviks mencapai 250.000 kematian (Rasjidi, 2010).

Berdasarkan data Surveilans Terpadu Penyakit, di Provinsi Bali kasus baru kanker serviks pada tahun 2016 sebanyak 1170 orang, untuk di Kota Denpasar pada tahun 2016 terdapat 834 kasus baru kanker serviks dan terdapat 12 orang meninggal dunia.

Berdasarkan data dari Yayasan Kerti Praja pada bulan Mei 2016 jumlah WPS di kota Denpasar sebanyak 2.169 orang. Di lihat dari faktor resiko terjadinya kanker serviks Wanita Pekerja Seks (WPS) dinilai paling berisiko untuk menderita kanker serviks karena sering berganti-ganti pasangan seksual dan melakukan hubungan seksual pada usia dini. Namun kenyataannya WPS masih belum memanfaatkan pelayanan kesehatan untuk melakukan pemeriksaan pap smear/IVA.

Oleh karena itu penulis tertarik untuk melakukan penelitian yang berjudul "Faktor Pendorong dan Penghambat Wanita Pekerja Seks (WPS) di Denpasar untuk Melakukan Pap Smear/IVA sebagai
Upaya Pencegahan Kanker Serviks Tahun 2017".

\section{METODE PENELITIAN}

Penelitian ini merupakan penelitian kuantitatif deskriptif dengan rancangan cross sectional, yang dilakukan di wilayah Kota Denpasar (Danau Tempe, Padang Galak, dan Carik). Sampel dalam penelitian ini sebanyak 82 orang dan pengambilan sampel dilakukan dengan metode quota sampling. Analisis yang dilakukan adalah analisis univariat dan analisis bivariat (tabulasi silang).

HASIL

\section{A. Analisis Univariat}

Tabel 1 Distribusi

Frekuensi Karakteristik Responden

\begin{tabular}{ccc}
\hline Karakteristik & $\mathrm{f} \mathrm{(82)}$ & $\%$ \\
\hline Umur & & \\
$\quad<35$ tahun & 61 & 74,4 \\
$\quad 35$ tahun & 21 & 25,6 \\
Pendidikan & & \\
$\quad$ Tinggi & 6 & 7,3 \\
Rendah & 76 & 92,7 \\
Daerah Asal & & \\
Bali & 1 & 1,2 \\
Luar Bali & 81 & 98,8 \\
\hline Total & $\mathbf{8 2}$ & $\mathbf{1 0 0}$ \\
\hline
\end{tabular}

Pada tabel 1 dapat dilihat bahwa proporsi umur responden $<35$ tahun lebih banyak dibandingkan umur responden $\geq 35$ tahun yaitu sebanyak $61 \quad(74,4 \%)$ responden. Untuk tingkat pendidikan responden terbanyak adalah pendidikan rendah yaitu sebanyak $76 \quad(92,7 \%)$ responden dan sebagian besar responden berasal dari luar Bali yaitu sebanyak 81 $(98,8 \%)$ responden. 
1. Faktor pendorong WPS melakukan pemeriksaan Pap Smear/IVA

Tabel 2 Distribusi Frekuensi Biaya Pap Smear, Biaya IVA dan Akses ke Fasilitas Kesehatan

\begin{tabular}{lcc}
\hline & $\mathrm{f}(82)$ & $\%$ \\
\hline Biaya Pap Smear & & \\
$\quad$ Terjangkau & 53 & 64,6 \\
$\quad$ Tidak terjangkau & 29 & 35,4 \\
Biaya IVA & & \\
$\quad$ Terjangkau & 82 & 100 \\
Akses ke Pelayanan & & \\
Kesehatan & & \\
$\quad$ Jauh & 26 & 31,7 \\
$\quad$ Dekat & 56 & 68,3 \\
\hline Total & $\mathbf{8 2}$ & $\mathbf{1 0 0}$ \\
\hline
\end{tabular}

Pada tabel 2 menunjukkan bahwa sebanyak $53 \quad(64,4 \%)$ responden mengatakan bahwa biaya pap smear terjangkau dan $100 \%$ responden mengatakan bahwa biaya IVA terjangkau. Sebesar 56 (68,3\%) responden mengatakan akses ke fasilitas kesehatan dekat.

2. Faktor penghambat WPS melakukan pemeriksaan Pap Smear/IVA

Tabel 3 Distribusi

Frekuensi

Pengetahuan, Sikap, Sumber

Informasi, Fasilitas dan Sarana

Prasarana, Dukungan Teman,

Dukungan Petugas Kesehatan

\begin{tabular}{lrc}
\hline & $\mathrm{f}(82)$ & $\%$ \\
\hline Pengetahuan & 3 & 3,7 \\
Baik & 14 & 17,1 \\
Cukup & 65 & 79,3 \\
Kurang & & \\
Sikap & 15 & 18,3 \\
Positif & 67 & 81,7 \\
Negatif & & \\
Informasi & 59 & 72 \\
Tidak pernah & 59
\end{tabular}

Pernah

23

28

Sumber informasi *

$\begin{array}{lcc}\text { Petugas kesehatan } & 21 & 56,8 \\ \text { Orang terdekat } & 10 & 27 \\ \text { Media massa } & 6 & 16,2\end{array}$

Fasilitas dan sarana

kesehatan

Tersedia dengan $19 \quad 23,2$

lengkap

Tidak tersedia

$63 \quad 76,8$

dengan lengkap

Dukungan teman

Mendukung

$12 \quad 14,6$

Tidak mendukung $\quad 70 \quad 85,4$

Dukungan petugas

kesehatan

\begin{tabular}{lll} 
Mendukung & 22 & 26,8 \\
Tidak mendukung & 60 & 73,2 \\
\hline Total & $\mathbf{8 2}$ & $\mathbf{1 0 0}$ \\
\hline
\end{tabular}

${ }^{*}$ Responden dapat menjawab lebih dari

1 responden

Hasil penelitian distribusi frekuensi pengetahuan menunjukkan bahwa sebagian besar responden berpengetahuan kurang yaitu sebanyak $65 \quad(79,3 \%)$ responden dan sebanyak $67 \quad(81,7 \%)$ responden bersikap negatif terhadap pencegahan kanker serviks.

Responden yang tidak pernah mendapatkan informasi tentang Kanker Serviks, Pap Smear dan IVA yaitu sebanyak 59 (72\%) responden dan responden yang pernah mendapatkan informasi sebagian besar mendapat informasi tentang Kanker Serviks, Pap Smear dan IVA dari petugas kesehatan yaitu sebanyak $21(56,8 \%)$ responden.

Sebanyak $63 \quad(76,8 \%)$ responden mengatakan bahwa fasilitas dan sarana kesehatan tidak tersedia dengan lengkap 
untuk memenuhi kebutuhan Pap Smear/IVA. Kemudian sebesar 70 (85,4\%) responden tidak mendapat dukungan dari teman dan sebesar $60(73,2 \%)$ responden tidak mendapat dukungan dari petugas kesehatan.

\begin{tabular}{|c|c|c|}
\hline \multicolumn{3}{|c|}{$\begin{array}{l}\text { Bersedia Melakukan Pap } \\
\text { Smear/IVA }\end{array}$} \\
\hline $\begin{array}{c}\text { Melakukan Pap } \\
\text { Smear/IVA }\end{array}$ & $\mathrm{f}(82)$ & $\%$ \\
\hline Ya (Bersedia) & 74 & 90,2 \\
\hline $\begin{array}{l}\text { Tidak (Tidak } \\
\text { bersedia) }\end{array}$ & 8 & 9,8 \\
\hline
\end{tabular}

\begin{tabular}{lll}
\hline Total & 82 & 100 \\
\hline
\end{tabular}

Hasil penelitian menunjukkan dari 82 responden sebesar $74(90,2 \%)$ responden bersedia untuk melakukan Pap Smear/IVA. Dari 74 responden yang bersedia melakukan Pap Smear/IVA mengatakan alasan bahwa mereka bersedia melakukan pemeriksaan tersebut dengan alasan karena ingin mengetahui status kesehatan sendiri dan 8 responden yang tidak bersedia melakukan pemeriksaan disebabkan karena mereka takut dan tidak punya waktu.

\section{B. Analisis Bivariat}

Tabel 5 Tabulasi Silang (Crosstab)

\begin{tabular}{ccccc}
\hline & \multicolumn{3}{c}{ Kesediaan melakukan } \\
& \multicolumn{3}{c}{ Pap Smear/IVA } \\
& Ya & & Tidak \\
\hline f & $\%$ & f & $\%$ \\
\hline
\end{tabular}

\begin{tabular}{lllll}
\hline Umur & & & & \\
$\quad<35$ tahun & 56 & 91,8 & 5 & 8,2 \\
$\geq 35$ tahun & 18 & 85,7 & 3 & 14,3 \\
Pendidikan & & & & \\
$\quad \begin{array}{l}\text { Tinggi (SMA, } 6 \\
\text { perguruan }\end{array}$ & & 100 & 0 & 0 \\
$\quad$ \\
tingi)
\end{tabular}

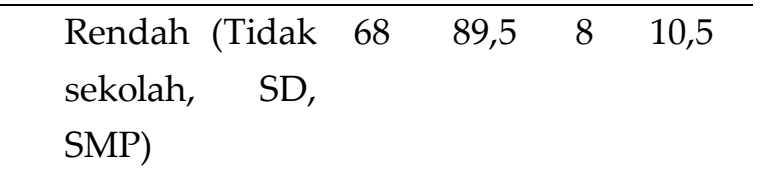

\section{Daerah Asal}

$\begin{array}{lllll}\text { Bali } & 1 & 100 & 0 & 0 \\ \text { Luar bali } & 73 & 90,1 & 8 & 9,9\end{array}$

Pengetahuan

$\begin{array}{lllll}\text { Baik } & 3 & 100 & 0 & 0 \\ \text { Cukup } & 14 & 100 & 0 & 0 \\ \text { Kurang } & 57 & 87,7 & 8 & 12,3\end{array}$

\section{Sikap}

$\begin{array}{lllll}\text { Positif } & 15 & 100 & 0 & 0 \\ \text { Negatif } & 59 & 88,1 & 8 & 11,9\end{array}$

\section{Sumber}

informasi

$\begin{array}{lllll}\text { Tidak Pernah } & 51 & 86,4 & 8 & 13,6 \\ \text { Pernah } & 23 & 100 & 0 & 0\end{array}$

Fasilitas dan sarana kesehatan

$\begin{array}{lllll}\begin{array}{l}\text { Tersedia } \\ \text { dengan }\end{array} & 19 & 100 & 0 & 0 \\ \text { lengkap } & & & & \\ \begin{array}{l}\text { Tidak } \\ \text { tersedia }\end{array} & 55 & 87,3 & 8 & 12,7 \\ \begin{array}{l}\text { dengan } \\ \text { lengkap }\end{array} & & & & \\ & & & & \end{array}$

\begin{tabular}{|c|c|c|c|c|}
\hline $\begin{array}{l}\text { Akses ke } \\
\text { Pelayanan }\end{array}$ & & & & \\
\hline Kesehatan & 19 & 73,1 & 7 & 26,9 \\
\hline Jauh & 55 & 98,2 & 1 & 1,8 \\
\hline Dekat & & & & \\
\hline Biaya pap smear & 50 & 94,3 & 3 & 5,7 \\
\hline Terjangkau & 24 & 82,8 & 5 & 17,2 \\
\hline Tidak & & & & \\
\hline terjangkau & & & & \\
\hline Biaya IVA & 74 & 90,2 & 8 & 9,8 \\
\hline Terjangkau & & & & \\
\hline Dukungan teman & 12 & 100 & 0 & 0 \\
\hline Mendukung & 62 & 88,6 & 8 & 11,4 \\
\hline Tidak & & & & \\
\hline mendukung & & & & \\
\hline Dukungan & & & & \\
\hline
\end{tabular}




$$
\text { petugas }
$$

\section{kesehatan}

$\begin{array}{llll}22 & 100 & 0 & 0\end{array}$

$\begin{array}{lllll}\text { Mendukung } 52 & 86,7 & 8 & 13,3\end{array}$

Tidak

mendukung

\begin{tabular}{lllll}
\hline Total & 74 & 90,2 & 8 & 9,8
\end{tabular}

Pada hasil tabulasi silang Tabel 5 dapat di lihat bahwa sebagian besar Wanita Pekerja Seks bersedia untuk melakukan pemeriksaan Pap Smear/IVA.

\section{DISKUSI}

\section{Karakteristik Responden}

Karakteristik umur responden pada hasil penelitian ini sebagian besar WPS-L di Kota Denpasar berumur $<35$ tahun yaitu sebanyak $74,4 \%$ dan sebagian besar responden berasal dari luar Bali yaitu sebanyak 98,8\% responden.

Pada penelitian yang dilakukan Hermanto (2016) didapatkan hasil bahwa sebagian besar WPS-TL di Kecamatan Tenayan Raya Pekanbaru berumur < 35 tahun yaitu sebanyak $97 \%$.

Menurut Taufan Nugroho (2014) kanker serviks biasanya menyerang wanita berusia 35-55 tahun. Untuk itu wanita yang berumur > 35 tahun diharapkan dapat lebih mengerti dan paham tentang kanker serviks karena mereka berada dalam rentang umur insiden tinggi kanker serviks.

Sebagian besar WPS-L di kota Denpasar memiliki pendidikan rendah (tidak sekolah, SD, SMP) yaitu 92,7\%. Hal ini sejalan dengan penelitian yang dilakukan oleh Kurniawan (2008) di lokalisasi Gang Dolly Surabaya mendapatkan hasil bahwa sebagian besar WPS berpendidikan rendah, responden beralasan bekerja sebagai WPS karena kesulitan ekonomi dan mengikuti keluarga yang juga bekerja sebagai WPS.

Menurut Yuliwati (2012) rendah atau tingginya tingkat pendidikan tanpa diikuti kemauan belajar dan rasa ingin tahu yang tinggi untuk mencari informasi, tidak menjamin mendapat tingkat pengetahuan yang baik.

Hal ini sependapat dengan penelitian yang telah dilakukan di Kota Denpasar bahwa responden yang berpendidikan rendah sebanyak $89,5 \%$ bersedia untuk melakukan pemeriksaan Pap Smear/IVA. Hal ini dikarenakan wanita pekerja seks memiliki rasa ingin tahu yang tinggi tentang status kesehatannya sendiri sehingga mereka bersedia melakukan pemeriksaan Pap Smear/IVA.

\section{Faktor pendorong WPS melakukan} pemeriksaan Pap Smear/IVA

\section{a. Biaya Pap Smear/IVA}

Hasil penelitian ini menunjukkan bahwa sebagian besar WPS mengatakan bahwa biaya pemeriksaan Pap Smear terjangkau yaitu $64,6 \%$ dan seluruh responden $(100 \%)$ mengatakan bahwa biaya untuk pemeriksaan IVA terjangkau. Kemudian pada hasil tabulasi silang didapatkan hasil bahwa responden yang mengatakan biaya Pap Smear terjangkau sebanyak 94,3\% bersedia melakukan pemeriksaan Pap Smear dan untuk yang mengatakan biaya IVA terjangkau sebesar $90,2 \%$ bersedia melakukan pemeriksaan IVA.

Hasil penelitian ini sesuai dengan Teori Lawrence Green yang mengatakan bahwa keterjangkauan biaya merupakan faktor pemungkin untuk seseorang melakukan tindakan kesehatan. Biaya kesehatan juga mempengaruhi seseorang untuk 
berperilaku dalam mendapatkan pengobatan.

Pada penelitian yang dilakukan oleh Eminia (2016) juga mendapatkan hasil tidak ada pengaruh antara keterjangkauan biaya dengan perilaku WUS dalam melakukan pemeriksaan kanker serviks.

\section{b. Akses ke fasilitas kesehatan}

Penelitian ini mendapatkan hasil bahwa sebagian besar WPS di wilayah kota Denpasar memiliki jarak yang dekat dengan fasilitas kesehatan yaitu sebesar $68,3 \%$ dan responden yang mengatakan jarak antara tempat tinggal dengan fasilitas kesehatan dekat sebesar 98,2\% bersedia untuk melakukan Pap Smear/IVA.

Hasil penelitian ini sesuai dengan teori Lawrence Green yang menyatakan bahwa jarak dan ketersediaan transportasi merupakan faktor pemungkin seseorang untuk dapat mengubah perilakunya dalam mencari pengobatan dan mendapatkan pelayanan kesehatan.

Penelitian yang dilakukan oleh Yuliwati (2012) juga mendapatkan hasil bahwa sebagian besar responden mengatakan keterjangkauan jarak/ tempat layanan dekat yaitu $65,6 \%$ sehingga terdapat hubungan yang signifikan antara keterjangkauan jarak/tempat layanan dengan pemeriksaan IVA.

\section{Faktor penghambat WPS melakukan pemeriksaan Pap Smear/IVA}

\section{a. Pengetahuan}

Menurut Notoatmodjo

pengetahuan merupakan hasil pengindraan manusia atau hasil tahu seseorang terhadap objek melalui indra yang dimilikinya dan pengetahuan seseorang terhadap objek mempunyai tingkat yang berbeda-beda, pengetahuan juga dapat diperoleh dari pengalaman sendiri atau pengalaman orang lain. Tindakan yang didasari pengetahuan akan lebih langgeng dibandingkan tanpa didasari pengetahuan.

Sebagian besar WPS-L di Kota Denpasar memiliki pengetahuan kurang yaitu sebesar 79,3\%. Hal ini disebabkan karena kurangnya informasi yang didapat oleh WPS dan kurangnya penyuluhan dari petugas kesehatan mengenai Kanker serviks, Pap smear dan IVA.

Hasil penelitian ini sejalan dengan penelitian yang Abdul Aziz (2016) yang mendapatkan hasil bahwa sebagian besar WPS-TL di Kecamatan Marpoyan Damai Pekanbaru memiliki pengetahuan kurang, hal ini disebabkan karena mayoritas responden memiliki tingkat pendidikan rendah dan kurangnya kemauan responden menggali informasi tentang penyakit kanker serviks.

Namun meskipun tingkat pengetahuan WPS di Kota Denpasar yang sebagian besar kurang tentang kanker serviks, Pap Smear maupun IVA nyatanya sebanyak $87,7 \%$ bersedia untuk melakukan pemeriksaan Pap Smear/IVA.

\section{b. Sikap}

Berdasarkan hasil penelitian didapatkan bahwa sebagian besar WPS memiliki sikap negatif tentang pencegahan kanker serviks yaitu sebanyak $81,7 \%$. Hal ini disebabkan karena tingkat pengetahuan responden yang sebagian besar rendah tentang kanker serviks dan sebagian besar responden belum pernah mendapatkan informasi tentang pencegahan kanker serviks. Berdasarkan hasil penelitian responden yang bersikap negatif sebanyak $88,1 \%$ bersedia melakukan pap smear/IVA. 
Hal ini sependapat dengan Azwar dalam buku Ahmad Kholid (2014) yang mengatakan bahwa sikap dan tindakan sering kali jauh berbeda. Hal ini karena tindakan nyata ditentukan tidak hanya oleh sikap akan tetapi oleh berbagai faktor eksternal lainnya yang berada di masyarakat seperti politik, sosial, budaya dan lingkungan. Sikap tidaklah sama dengan perilaku, dan perilaku tidaklah selalu mencerminkan sikap seseorang, sebab seringkali terjadi bahwa seseorang memperlihatkan tindakan yang bertentangan dengan sikapnya.

Penelitian yang dilakukan Indah Siti (2016) juga mendapatkan hasil bahwa tidak ada hubungan antara sikap dengan kesediaan WUS dalam melakukan deteksi dini kanker serviks.

\section{c. Sumber informasi}

Hasil penelitian menunjukkan bahwa responden yang tidak pernah mendapatkan informasi tentang Kanker Serviks, Pap Smear dan IVA yaitu sebesar $72 \%$. Hal ini disebabkan karena responden hanya mendapatkan informasi tentang $\mathrm{HIV}$, IMS dan pentingnya menggunakan kondom saat berhubungan seksual dari petugas kesehatan.

Pada hasil penelitian ditemukan juga bahwa responden responden yang tidak pernah mendapat sumber informasi sebanyak $86,4 \%$ bersedia melakukan pemeriksaan pap smear/IVA. Hal ini dimungkinkan karena adanya opini publik yang menyatakan bahwa penyakit kanker serviks sangat berbahaya bagi seorang wanita sehingga wanita pekerja seks merasa takut apabila tidak melakukan pemeriksaan Pap Smear/IVA.

Hal ini berbeda dengan hasil penelitian yang dilakukan oleh Rohmawati (2010) menyatakan bahwa keterpaparan individu terhadap informasi kesehatan akan mendorong terjadinya perilaku hidup sehat.

\section{d. Fasilitas dan Sarana Kesehatan}

Pada hasil penelitian didapatkan bahwa responden yang mengatakan fasilitas dan sarana kesehatan tidak tersedia dengan lengkap untuk melakukan pemeriksaan Pap Smear/IVA yaitu sebesar $76,8 \%$.

Wanita pekerja seks yang mengatakan bahwa fasilitas dan sarana kesehatan tidak tersedia dengan lengkap sebesar 87,3\% bersedia untuk melakukan pemeriksaan Pap Smear/IVA. Hal ini disebabkan karena wanita pekerja seks ingin mengetahui status kesehatannya sendiri, dan kemungkinan nantinya wanita pekerja seks tersebut akan menuju ke fasilitas kesehatan yang lebih lengkap agar bisa melakukan pemeriksaan Pap Smear/IVA.

Hal ini sependapat dengan Elok (2013) mendapatkan hasil bahwa tidak ada hubungan antara ketersediaan sarana kesehatan dengan praktik pemeriksaan Pap Smear.

\section{e. Dukungan Teman}

Sebagian besar Wanita Pekerja Seks di Kota Denpasar tidak mendapatkan dukungan dari teman yaitu sebesar $85,4 \%$. Teori Lawrence Green dalam Priyoto (2014) mengatakan bahwa dukungan teman merupakan faktor pendorong atau penguat dari individu untuk berperilaku. Namun hal ini berbeda dengan hasil penelitian didapatkan bahwa sebanyak $88,6 \%$ yang tidak mendapat dukungan dari teman bersedia untuk melakukan Pap Smear/IVA. 
Hal ini berbeda dengan yang dilakukan oleh Affi Zakiyya (2015) yang mendapatkan hasil bahwa ada hubungan antara dukungan teman dengan kesediaan wanita dalam melakukan deteksi dini kanker serviks

\section{f. Dukungan Petugas Kesehatan}

Hasil penelitian di Kota Denpasar menunjukkan bahwa sebagian besar WPS tidak mendapatkan dukungan dari petugas kesehatan yaitu sebesar $73,2 \%$.

Hal ini dikarenakan petugas kesehatan tidak pernah memberikan informasi atau penyuluhan dan petugas kesehatan juga tidak pernah mengajak WPS untuk melakukan pemeriksaan Pap Smear/IVA sehingga hal ini bisa menyebabkan kurang sadarnya WPS untuk memeriksaan kesehatannya sendiri.

Menurut Lawrence Green dalam Priyoto (2014), faktor dari tenaga kesehatan itu sebagai pendorong atau penguat dari individu untuk berperilaku. Hal ini dikarenakan petugas kesehatan tersebut ahli dibidangnya sehingga dijadikan tempat untuk bertanya dan pemberi input atau masukan untuk pemanfaatan pelayanan kesehatan.

Penelitian Eminia (2016) mengatakan bahwa wanita yang mendapatkan dukungan dari petugas kesehatan memiliki keikutsertaan pemeriksaan kanker serviks lebih tinggi dibandingkan dengan wanita yang kurang mendapatkan dukungan dari petugas kesehatan.

Namun pada hasil penelitian ini berbeda dengan hasil penelitian yang sebelumnya. Walaupun sebagian besar wanita pekerja seks tidak mendapatkan dukungan dari petugas kesehatan namun sebagian besar WPS bersedia untuk melakukan pemeriksaan Pap Smear/IVA yaitu sebesar 86,7\%. Hal ini disebabkan karena wanita perja seks ingin mengetahui status kesehatannya sendiri sehingga mereka bersedia melakukan pemeriksaan Pap Smear/IVA.

\section{SIMPULAN DAN SARAN}

Mayoritas responden berumur $<35$ tahun sebanyak $74,4 \%$ responden, kemudian sebanyak $92,7 \%$ responden berpendidikan rendah dan sebesar 98,8\% responden berasal dari luar Bali.

Faktor pendorong wanita pekerja seks untuk melakukan Pap Smear/IVA sebagai upaya pencegahan kanker serviks adalah sebanyak $64,6 \%$ responden mengatakan biaya Pap Smear terjangkau dan seluruh responden $(100 \%)$ mengatakan biaya IVA terjangkau, serta sebanyak 68,3\% responden mengatakan akses ke fasilitas kesehatan jaraknya dekat antara tempat tinggal responden ke fasilitas kesehatan.

Faktor penghambat wanita pekerja seks untuk Pap Smear/IVA sebagai upaya pencegahan kanker serviks adalah sebanyak 79,3\% responden berpengetahuan rendah, sebesar $81,7 \%$ responden memiliki sikap negatif terhadap pencegahan kanker serviks, sebesar $72 \%$ responden tidak pernah mendapatkan sumber informasi tentang kanker serviks, Pap Smear maupun IVA, sebesar 76,8\% responden mengatakan fasilitas dan sarana kesehatan tidak tersedia dengan lengkap, sebesar 85,4\% responden tidak mendapatkan dukungan dari teman dan sebesar $73,2 \%$ tidak mendapatkan dukungan dari petugas kesehatan.

Bagi petugas puskesmas khususnya pemegang program KIA diharapkan dapat 
bekerja sama dengan LSM untuk memberikan edukasi tentang kanker serviks, Pap Smear dan IVA kepada wanita pekerja seks melalui penyuluhan.

\section{DAFTAR PUSTAKA}

Aminati, Dini. (2013). Cara Bijak Menghadapi dan Mencegah Kanker Leher Rahim (Serviks). Brilliant Books: Yogyakarta.

American Cancer Society. (2015). Global Cancer Facts \& Figures 3rd Edition. Atlanta:American Cancer Society. Available at: http://www.cancer.org/content/dam/canc er-org/research/cancer-facts-andstatistics/global-cancer-facts-andfigures/global-cancer-facts-and-figures3rd-edition.pdf. Diakses tanggal 22 Januari 2017

Elok, Nathalia. (2013). Faktor-Faktor yang Berhungan dengan Praktik Pemeriksaan Pap Smear pada Wanita Bekerja (Studi Kasus di Dinas Kesehatan Kota Semarang Tahun 2012).

Hermanto., dkk. (2016). Hubungan Pengetahuan dan Sikap Terhadap Tindakan Wanita Pekerja Seksual Tidak Langsung Di Hotspot $X$ Kecamatan Tenayan Raya Pekanbaru Tentang Pap Smear dan Inspeksi Visual Asetat Sebagai Deteksi Dini Kanker Serviks. Jom Fk Volume 3 No.1. Februari 2016.

Kholid, Ahmad. (2014). Promosi Kesehatan dengan Pendekatan Teori Perilaku, Media, dan Aplikasinya. Rajawali Pers: Jakarta.

Kurniawan, Bayu., dkk. (2008). Hubungan Tingkat Pengetahuan dengan
Partisipasi pada Pemeriksaan Pap Smear pada Wanita Pekerja Seks Komersial. Jurnal Kedokteran Brawijaya, Vol. XXIV, No. 3, Desember 2008

Notoatmodjo, Soekidjo. (2014). Ilmu

Perilaku Kesehatan. Rineka Cipta: Jakarta.

Nugroho, Taufan \& Bobby Indra. (2014). Masalah Kesehatan Reproduksi Wanita. Nuha Medika: Yogyakarta.

Priyoto. (2014). Teori Sikap dan Perilaku dalam Kesehatan. Nuha Medika: Yogyakarta.

Rasjidi, Imam. (2010). Epidemiologi Kanker Pada Wanita. CV Sagung Seto: Jakarta.

Rohmawati, Ika. (2010). Faktor-Faktor yang Berhubungan dengan Perilaku Wanita Usia Subur Dalam Deteksi Dini Kanker Serviks dengan Metode IVA (Inspeksi Visual Dengan Asam Asetat) di Wilayah Kerja Pukesmas Ngawen I Kabupaten Gunung Kidul Tahun 2011. Skripsi. Jakarta: FKM UI.

Siti, Indah. (2016). Faktor-Faktor yang Mempengaruhi Kesediaan WUS dalam Melakukan Deteksi Dini Kanker Serviks di Puskesmas Manahan Surakarta

Yuliwati. (2012). Faktor-Faktor yang Berhubungan dengan Perilaku WUS dalam Deteksi Dini Kanker Leher Rahim Metode IVA di Wilayah Puskesmas Prembun Kabupaten Kebumen Tahun 2012. Skripsi. Jakart : FKM UI.

Zakiyya, Affi., dkk. (2015). Faktor-Faktor yang Berpengaruh Terhadap 
Arc. Com. Health • Desember 2018

ISSN: 2527-3620

Vol. 5 No. $2: 1-10$

Penggunaan Deteksi Dini Kanker Serviks. 